\title{
Waltz with Development: Insights on the developmentalization of climate-induced migration
}

\author{
Giovanni Bettini ${ }^{1}$ and Giovanna Gioli ${ }^{*}$ \\ 1: Lancaster Environment Centre, Lancaster University, Lancaster LA1 4YQ, UK. Email: \\ g.bettini@lancaster.ac.uk \\ 2: Centre for Earth Science and Sustainability-CEN, Institute of Geography, University of \\ Hamburg, Hamburg, Germany. Email: giovanna.gioli@icimod.org
}

* Current affiliation: International Centre for Integrated Mountain Development, ICIMOD, Kathmandu, Nepal

\section{Introduction}

Human mobility amidst environmental change constitutes the overwhelming reality in most of the 'Global South', where wider processes of change such as urbanization, land use transition, globalization, and postcolonial relations are inextricably interwoven. It should therefore be a platitude to say that migration, development and global environmental change are strongly inter-related - and one would expect this to be the starting point of any informed discussion on the nexus between climate change and human mobility. However, this was not the case for the debates on climate-induced migration that flourished in early 1990s. They were brought into the limelight by the controversial figure of the climate refugee and the fear of the security implications of environmentally-induced mass displacement. Thereby, the question of 'development' was not central in the environmental sciences-dominated debate on the climate-migration nexus, although vulnerability to environmental/climate change and the causes of displacement are rooted in socio-economic marginalization (what is often referred to as a lack of development). Conversely, although the nexus between migration and (global) environmental change has been informed by a more or less explicit North-South dichotomy, it has been neglected by scholars in the field of 'migration and development' and by international fora such as the Global Forum on Migration and Development or the High Level Dialogue on Migration and Development.

Things have recently changed. The old debates have been shaken by the emergence of discourses that put development at the center of stage ${ }^{1}$. Mobility is still understood as a

\footnotetext{
1 To be sure, the 'old' alarmist narratives and the securitizing tendencies have not completely disappeared see for instance the ambiguous tone in IPCC's AR5 ch 12 (2014), and the recent discussions on the role of climatic changes in the ongoing Syrian conflict (Kelley et al. 2015). The spectre of mounting waves of climate refugees still titillates the imagination of media outlets, see for instance recent pieces in popular outlets such
} 
response to sudden events and slow-onset environmental degradation, but (governed) voluntary migration is also promoted as a legitimate, proactive adaptation strategy aimed at reducing the vulnerability of population at risk (Black et al. 2011). The 'migration as adaptation' thesis resides on the recognition of migrants' economic agency and in the hope that remittances will be invested by households and communities to build resilience (Warner and Afifi 2013). Mobility is thus viewed also as a mechanism that can foster development and thereby reduce vulnerability - clearly striking chords linked to the wider debate on 'migration and development'. In turn, a series of high-level actors in the field of migration and development policy and advocacy, such as the World Bank, the Asian Development Bank (ADB) and the International Organization for Migration (IOM), have engaged with the question of climate-related migration.

This article looks closer at this 'developmentalization' of the debate on climate migration; it explores the way the emerging discourses conceptualize mobility and its relation to adaptation and development. The article will highlight that (a) conceptually, the emerging models and narratives on the environmental change-migration nexus can be hardly understood in isolation from a series of long-standing debates in the fields of development and migration; (b) in terms of institutions and regimes, the interactions between mainstream circles concerned with these intertwined phenomena (which used to be scant) are becoming more intense and substantial. Moreover, the following will show how, in spite of their novelty in the context of climate adaptation, the emerging discourses are brewed out of ingredients that are not new and are contested. The 'migration as adaptation' thesis is built on theoretical premises drawn from a strategic merging of New Economic of Labour Migration (hereafter NELM) and Sustainable Livelihood approaches, articulated in ways that reproduce the neoliberal version of the classical optimist take on the migration-development nexus. The extent to which this evolution represents a step forward is yet to be understood.

After gathering a few salient highlights on the evolutions of the debate on 'migration and development' (section 2), the article traces the changing understanding of mobility underlying the discourses on climate-induced migration; it puts in relation the initial environmental determinism and pathologization of mobility with the debate's segregation from the migration and development community (section 3). The 'deenvironmentalizaiton' and 'developmentalization' of the discourses are documented and situated in relation to the 'migration and development' literature (sections 4). Before

as The Independent (http://goo.gl/fMbCJA), The Guardian (http://goo.gl/LP37HV), The National Observer (http://goo.gl/ABcIPm). 
concluding, the article offers some critical remarks (section 5) on the implications of such evolutions, in dialogue with a number of recent critical studies.

\section{Migration and Development: Between optimism and pessimism}

As the following sections will reveal in greater detail, the various discourses on climate migration that have emerged over time reside on very different understandings of the ways in which migration relates to socio-economic development. Although this is not often acknowledged, such understandings owe a lot to the long-standing debates on 'migration and development' that have animated scholarship and practitioners over several decades. As a first step in our analysis, this section offers a few insights on the evolution of such broader debates, which will prove useful to evaluate the discourses on climate change and migration.

To begin with, views on the synergies between migration and development have periodically changed sign over time. Most of the authors who have engaged in a critical analysis of the relationship between migration and development identify the same three phases in the evolution of the post-war debate on migration and development (cf. Table 1 for a summary). Leaving aside minor differences in periodization, such evolution is characterized as swinging from optimistic to pessimistic perspectives on the capability of migration to make a difference for development (Spaan 2005, Faist 2009, De Haas 2010, 2012, Gamlen 2014).

The phases identified by the literature are a post-war developmentalist optimism stretching to the 1960s, followed by a Marxist pessimism over the 1970s and 1980s, which leaves the way to a new optimistic view in the 1990s and 2000s, largely driven by empirical work based on NELM approach and by the enthusiasm for surging remittances (cf. Ratha 2003). In a nutshell, while the phases of pessimism focus on structural constraints at the macro-level, largely shaped by labour markets dynamics, the optimism celebrates the agency of the migrants and their ability to "help themselves" via rising and better invested remittance inflows.

Table 1: Brief timeline of debates, modified following de Haas 2010: 230

\begin{tabular}{|l|l|l|l|l|l|}
\hline Period & $\begin{array}{l}\text { Research } \\
\text { community } \\
\text { (Mig \& Dev) }\end{array}$ & $\begin{array}{l}\text { Research } \\
\text { community (Mig \& } \\
\text { CC) }\end{array}$ & $\begin{array}{l}\text { Policy Field } \\
\text { ( Mig \& Dev })\end{array}$ & $\begin{array}{l}\text { Policy Field } \\
\text { (Mig \& CC) }\end{array}$ & $\begin{array}{l}\text { Economic } \\
\text { Phase in } \\
\text { OECD } \\
\text { countries }\end{array}$ \\
\hline $\begin{array}{l}\text { Until } \\
1973\end{array}$ & $\begin{array}{l}\text { Migration \& } \\
\text { Development } \\
\text { Optimism }\end{array}$ & ----- & $\begin{array}{l}\text { Developmentalist } \\
\text { views; capital and } \\
\text { knowledge- } \\
\text { transfers by } \\
\text { migrants would help }\end{array}$ & & $\begin{array}{l}\text { Post-war } \\
\text { boom in } \\
\text { Europe and } \\
\text { North } \\
\text { America }\end{array}$ \\
\hline
\end{tabular}




\begin{tabular}{|c|c|c|c|c|c|}
\hline & & & $\begin{array}{l}\text { LDC's development } \\
\text { "remittances and } \\
\text { return" (Faist 2009) }\end{array}$ & & \\
\hline $\begin{array}{l}1973- \\
1990\end{array}$ & $\begin{array}{l}\text { Migration \& } \\
\text { Development } \\
\text { Pessimism } \\
\text { (Dependency, } \\
\text { brain drain) }\end{array}$ & $\begin{array}{l}\text { The environment } \\
\text { virtually absent from } \\
\text { the migration } \\
\text { scholarship }\end{array}$ & $\begin{array}{l}\text { "Vicious circle" } \\
\text { Skepticism; brain } \\
\text { drain; after } \\
\text { experiments with } \\
\text { return migration } \\
\text { policies focused on } \\
\text { integration in } \\
\text { receiving countries. } \\
\text { Migration largely } \\
\text { out of sight in } \\
\text { development field, } \\
\text { tightening of } \\
\text { immigration } \\
\text { policies. }\end{array}$ & $\begin{array}{l}\text { First mention of } \\
\text { 'environmental } \\
\text { refugees' in UNEP } \\
\text { paper (El Hinnawi } \\
1985 \text { ) }\end{array}$ & Oil shocks \\
\hline $\begin{array}{l}1990- \\
2001\end{array}$ & $\begin{array}{l}\text { Readjustment to } \\
\text { more subtle views } \\
\text { under influence of } \\
\text { empirical work } \\
\text { (NELM, SLA, } \\
\text { Transnationalism) }\end{array}$ & $\begin{array}{l}\text { "Maximalist phase" } \\
\text { "Climate refugees" } \\
\text { hypothesis; } \\
\text { securitization }\end{array}$ & $\begin{array}{l}\text { Persistent } \\
\text { skepticism and near- } \\
\text { neglect of the issue; } \\
\text { "migration and } \\
\text { development, } \\
\text { nobody believes } \\
\text { that anymore" } \\
\text { (Taylor et al., 1996a: } \\
\text { 401) further } \\
\text { tightening } \\
\text { of immigration } \\
\text { policies. }\end{array}$ & $\begin{array}{l}\text { Principle of causal } \\
\text { attribution at the } \\
\text { forefront. }\end{array}$ & $\begin{array}{l}\text { High-tech } \\
\text { and housing } \\
\text { booms }\end{array}$ \\
\hline $\begin{array}{l}>2001- \\
2011\end{array}$ & $\begin{array}{l}\text { Boom in research, } \\
\text { in particular on } \\
\text { remittances. } \\
\text { Generally positive } \\
\text { view. }\end{array}$ & $\begin{array}{l}\text { "Minimalist phase" } \\
\text { Critique of the } \\
\text { concept of "climate } \\
\text { refugees" and } \\
\text { gradual shift towards } \\
\text { migration as positive } \\
\text { form of adaptation }\end{array}$ & $\begin{array}{l}\text { "Virtuous circle" } \\
\text { Resurgent optimism } \\
\text { under influence of } \\
\text { remittance boom, } \\
\text { and sudden } \\
\text { turnaround of } \\
\text { views: remittances, } \\
\text { brain gain, diaspora } \\
\text { Involvement seen as } \\
\text { "triple win". } \\
\text { "celebration of } \\
\text { circulation" (Faist } \\
\text { 2009). Development } \\
\text { contribution of } \\
\text { migration often } \\
\text { framed within } \\
\text { renewed } \\
\text { hopes put on } \\
\text { circular and return } \\
\text { migration }\end{array}$ & $\begin{array}{l}\text { Exploration of existing } \\
\text { (e.g. Geneva } \\
\text { Convention) and new } \\
\text { legal frameworks } \\
\text { (Biermann and Boas } \\
\text { 2008; 2010) for the } \\
\text { protection of 'climate } \\
\text { refugees', expected in } \\
\text { large numbers. } \\
\text { Increasing recognition } \\
\text { of the role of mobility } \\
\text { in the context of } \\
\text { (global) environmental } \\
\text { change in international } \\
\text { fora (e.g. Cancun) }\end{array}$ & $\begin{array}{l}\text { Financial } \\
\text { crises in } \\
\text { industrialized } \\
\text { countries; } \\
\text { recession }\end{array}$ \\
\hline$>2011$ & $\begin{array}{l}\text { Some authors talks } \\
\text { of new Pessimism } \\
\text { (Skeldon, Gamlen, } \\
\text { Faist) } \\
\text { Critique of the } \\
\text { neoliberal } \\
\text { underpinnings of } \\
\text { migration as self } \\
\text { help development }\end{array}$ & $\begin{array}{l}\text { More empirical work } \\
\text { grounded on NELM } \\
\text { + SLA approaches, } \\
\text { prominence of the } \\
\text { 'migration as } \\
\text { adaptation' thesis; } \\
\text { migration in the } \\
\text { context of (global) } \\
\text { environmental } \\
\text { change framed as } \\
\text { livelihood } \\
\text { diversification and }\end{array}$ & $\begin{array}{l}\text { Continued emphasis } \\
\text { on remittances and } \\
\text { diaspora. Matching } \\
\text { fund and increased } \\
\text { role of South-South } \\
\text { migration }\end{array}$ & $\begin{array}{l}\text { Fragmentation of the } \\
\text { issue (displacement, } \\
\text { relocation, trapped } \\
\text { population, } \\
\text { adaptation); } \\
\text { Mainstreaming of } \\
\text { migration in National } \\
\text { Adaptation Plan } \\
\text { (IOM 2014). } \\
\text { Emphasis on } \\
\text { remittances and South- } \\
\text { South circulation }\end{array}$ & $\begin{array}{l}\text { Financial } \\
\text { crises in } \\
\text { industrialized } \\
\text { countries }\end{array}$ \\
\hline
\end{tabular}




\begin{tabular}{|l|l|l|l|l|}
\hline & $\begin{array}{l}\text { risk mitigation } \\
\text { strategy }\end{array}$ & & \\
\hline
\end{tabular}

De Haas ascribes the swings between optimism and pessimism in the debate also to changing theoretical paradigms in social and development theory, namely to fundamental oppositions between structuralist and functionalist schools (de Haas 2010). Other authors have drawn attention to the fact that the phases have been mirroring economic cycles: optimism seem to prevail during phases of economic expansion (such as in the 1950s and 1960s), while pessimism surge in times of economic contraction, such as in the the 1970s or during the recent crises (Gamlen 2014: 590).

The first wave of optimism in the 1960s was based on developmentalist views, namely on the 'balanced growth approach' according to which migration would have spurred a "new equilibrium between capital and labor that eventually fosters development" (Spaan et al. 2005: 37). Such equilibrium relies on the "remittances and return" tenet (Faist 2009): while supplying labour to developed countries, migrants would help their countries of origin via remittances, and ideally return and invest there. After the failure of return migration policies, such as the notorious German Gastarbeiter schemes, pessimistic 'asymmetric growth' approach became dominant during the 1970s and 1980s. NeoMarxist pessimism focused on structural factors making the case for the increasing underdevelopment and dependency of the underdeveloped on the developed core countries (cf. Almeida 1973). Rather than to development, migration was considered to further contribute to North-South inequality causing brain drain, as well as inflation via non-productive usage of remittances. Remittances hence, ceased to be seen as a driver for sustainable growth opportunities but started to be blamed for the establishment of postcolonial dependencies.

As can be seen in Table 1, in the 1990s neoliberal development thinking began to advocate the "empowerment of communities and individuals themselves to undertake the 'development project'” (Faist 2008: 24). Thanks to the theoretical contribution of NELM and transnationalism, new empirical evidence contributed to mitigating the pessimism by focusing on the multiplier effects of remittances and the potential positive contributions of transnationally engaged migrants and "diasporas", now considered as an important players in development. The pragmatic view behind this is that remittances tend to act counter-cyclically and increase in time of economic shocks and conflict (Sriskandarajah 2002; Kapur 2005; Ratha 2005; Fagen and Bump 2006). The perceived positive impact of migration on sending regions has fuelled the valorization (and the rhetoric) of migrants as agents or even 'heroes' of development (Faist 2011). 
The proponents of the 'migration as adaptation' thesis, appropriated this conceptual framework and tested it in the context of environmental shocks (e.g. Paulson 1993; Laczko and Collett 2005; Bettin et al 2014, De le et al 2014) finding similar evidence, as well as momentum for praising the potential role of remittances in reducing vulnerability at the household and community levels.

As put by IOM:

"Since the establishment of the MDGs, migration has been acknowledged as a major driver of development in countries of origin and destination alike. Migration remittances to developing countries have reached the same level as major international capital flows for development. In a world that faces severe skills shortages on various levels, migration is already playing an essential role by filling labour market gaps. In the context of natural or manmade catastrophes and crises, remittances and migration can support the resilience of populations both staying and going". (IOM 2014)

We can clearly see in this passage, how resilience in the context of "natural disaster" 2 is integrated in the pre-existing narrative on migration and development.

Another key aspect, i.e. the so-called 'triple win' mantra, started gaining currency in the debate: If properly harnessed, remittances (both social and financial) can benefit all, sending countries, destination countries and migrant themselves. Despite its failure in the 1960s, 'circular migration' returns to be depicted as the most virtuous type of mobility, as it entails the sharing of know-how and labour between the less-developed South (supply) and the developed North (demand). Leading international bodies conceptualise migration prioritising circular migration (IOM 2005; The World Bank 2013; Hugo 2013; Betts 2011), more recently with explicit reference to the Post 2015 agenda and with an increasing focus on South-South migration (IOM 2014).

Several critical scholars have contributed to problematize the nexus between development and migration (e.g. Kapur 2004; de Haas 2008; 2010; Lindley 2009Piper 2009) and have cautioned against indulging in an often ungrounded "remittances euphoria", which underplays important factors at the meso and macro levels and often generalize success stories that are instead context-specific and hardly replicable.

Some authors have drawn attention to the fact that migration-and-development thinking is a cover for the immigration control agenda, highlighting that swings in the debate have mirrored the booms and busts in immigration economies (Gamlen 2014). Many have

\footnotetext{
2 As put by Basher, "the term 'natural disaster' is an oxymoron, as the vulnerability and coping factors in the equation are within human control to some degree and therefore are not "natural'" (Basher 2006: 2167)
} 
criticized the narrow focus on the entrepreneurial abilities of the migrant, who is expected to shoulder the burden of development alone. The emphasis on the agency of migrant can also be linked to neoliberal agendas where 'the idea of social responsibility [is] replaced by a neoliberalized care of the self' (see Evans and Reid 2013: 11-12). The narrow focus on remittances', i.e. self-help development 'from below' could "shift the attention away from structural constraints and the vital role of states in shaping favourable conditions for positive development impacts of migration to occur"(De Haas, 2010: 227). This contribution certainly does not aim at providing an exhausting account of the "migration and development debate", but the underscoring of its main trends and evolutions - as described by prominent scholars and summarized in table 1 - is instrumental to the analysis of the discourse on climate migration.

\section{The origins: Environmentally-induced separation}

To grasp the changing understanding of the links between mobility, environmental change and development, it is revealing to assess the context in which the concerns over the impacts of environmental degradation (including climate change) and human migration gained momentum.

The literature (e.g. Laczko and Aghazarm 2009; Foresight 2011; Gemenne 2011; White 2011; Morrissey 2012) locates the origins of the debates on the link global environmental change-migration in the early 1980s, when the UN Environmental Program (El-Hinnawi 1985 ) and then the World Watch Institute (Jacobsen 1988) published two reports on 'environmental refugees', a term in effect coined a few years earlier by Lester Brown (1976). The discourses on environmentally induced migration emerged within epistemic and policy circles committed to environmental stewardship, whose epistemological foundations and policy concerns ${ }^{3}$ were at loggerheads with the intellectual leanings and policy priorities prevalent among scholars and professionals working on migration and development. The question of environmentally induced migration was indeed dominated by an 'alarmist' (cf. Gemenne 2011 b) or 'maximalist' (cf. Morrissey 2009) approach, according to which "environmental disruptions, among which the impacts of climate change in particular, will induce massive population displacements" (Gemenne 2011 b: 225). By floating around impressive (and inaccurate) figures of forced migrants displaced by climate change, the alarmist or 'maximalist' coalition stressed the urgency of the threats posed by climate change putting the issue under the rubric of national security

3 for a thorough discussion of this point, see Bettini and Anderson (2014) 
more than of development. With a specific focus on the causative effect of climate change, the maximalist narrative pivots around the attempt to discern environmental drivers from other root-causes of mobility (e.g. poverty, conflict etc.) in order to produce estimates of potential 'environmental migrants' or 'climate refugees', often portrayed as a security threat, in future climate change scenarios (Suhrke 1994; Myers 1993, 1997, 2002; Stern 2007; Homer Dixon 1999; Reuveny 2007; WBGU 2008).

Environmental and climate refugees served as an emblematic portrayal of the dangers posed by environmental and climate change: in the liberal/humanitarian version, a plea for immediate efforts to address climate change in terms of both scholarly and financial commitment (Biermann and Boas 2010, Environmental Justice Foundation 2009, Christian Aid 2007); in the reactionary articulation, an exhortation to (more or less literally) close the ranks in preparation for the post-climate change chaos (Schwartz and Randall 2003; Council of the European Union 2008).

The reality of mobility amidst environmental change is of course far less linear, deterministic and media-friendly than what initially suggested. Projections of the number of climate refugees are grounded on a narrow environmental determinism, simply feeding the number of people living in places at risk into climate scenarios, without considering the degree of resilience and adaptive capacity of affected communities, as shaped by a multiplicity of social, economic, political and institutional factors (Black 2001; 2008; Barnett 2002; Gemenne 2011a; Jakobeit and Methmann 2012). Moreover, data are sparse and hard to harmonize (especially when it comes to the most vulnerable areas) and, despite the progresses, effective methods to model the complex interactions of environmental drivers with other socioeconomic forces are at a nascent stage (Kniveton et al. 2008; 2011; McLeman 2012). For all its merits, also the initial idea of harnessing the figure of the climate refugee for an extension of the Geneva Refugee Convention to include climate-displaced persons (Williams, 2008, Conisbee and Simms, 2003) has proven unfeasible. For instance, the UNHCR rejected the label 'environmental refugee' or 'climate refugee' on the grounds that the current legal category defining a refugee is linked to a notion of persecution and the crossing of an international border, which is not the case for environmentally induced displacement (Piguet 2008; Gemenne and Bruecker 2015). The enthusiasm around this project has significantly cooled down, leaving the ground to alternative and more ad hoc initiative to promote protection in the context of crossborder environmental displacement, such as the consultative process initiated by the 
Nansen Initiative 4.

It is not hard to understand why migration scholars and critical social scientists found the maximalist perspective indigestible - pushing instead a "minimalist" or "skeptical" approach. The maximalists' deterministic understanding of migration clashes with the recognition of the complexity, nuances and multi-causal nature of human mobility that informs contemporary migration studies. Moreover, the specter of mounting waves of climate refugees has been criticized for paving the way to a securitization of migration and to xenophobic sentiments (Hartmann, 2010, Smith, 2007, Oels 2008; Gill 2010; Oels 2013). Alarmist tones on the 'barbarians at the gate' (cfr. Bettini 2013) also conflict with the widespread efforts by migration advocacy groups to de-pathologize the figure of the migrant and to support her rights. On the other hand, it is fair to say that critical social scholarship have not, until recently, fully engaged with the question of how ongoing and future socio-ecological transformations will impact on human mobility5.

At the policy level, we see a similar situation. Climate change was initially absent from the radar screen of international bodies dealing with human mobility - when not actively avoided. The case of IOM is exemplary: as reported by Frank Laczko, head of the Migration Research Division at IOM, as recently as in 2006, he was told by its Member States: "Do not touch the environment. It has nothing to do with migration. It is not your concern" (Laczko 2008: 2). But things have changed fast.

\section{From climate-induced displacement to climate mobilities}

In recent years, new problematizations of the climate-migration nexus have emerged, and the topic, once confined to relatively marginal environmental (alarmist) arenas, has reached the top spheres of international policies circles, including those of development and migration.

\subsection{Mainstreaming climate migration}

To begin with, the question of migration has gained ground within the institutional scientific and policy agenda on climate change. It has formally been included in the UNFCCC process = notably in Paragraph 14 (f) of the Cancun Agreement (see on this Warner (2012)) and within the Warsaw International Mechanism for the definition of

\footnotetext{
${ }^{4}$ Launched in 2012, the Nansen Initiative is a state-led, bottom-up consultative process intended to build consensus on the development of a protection agenda addressing the needs of people displaced across international borders in the context of drought, flooding and other natural hazards, including those linked to the effects of climate change. (www.nanseninitiative.org/)

${ }^{5}$ According to the leading migration scholar Stephen Castle, his discipline has until recently neglected the role played by environmental change, an important factor in human mobility since centuries, and likely to become more and more relevant in the context of climate change (Castles 2011).
} 
'Loss and Damage' (James et al. 2014). The Intergovernmental Panel on Climate Change (IPCC 2014) has devoted an increased attention to the matter, in particular in chapter 12 of its latest assessment report.

Climate migration has also entered key international arenas on migration. IOM - again, a good barometer of trends in mainstream migration scholarship and advocacy - has now become one of the major international players addressing the issue of 'environmental migration'. For instance, in December 2014, IOM has launched the Environmental Migration Portal "Knowledge Platform on people on the move in a changing climate to facilitate dialogue and information sharing" 6 . Also, in line with the wider and fast growing agenda advocating for "adaptive development" (Agrawal and Lemos 2015), IOM is coordinating several initiatives aimed at mainstreaming development and migration as a positive form of adaptation to (global) environmental change. IOM has also developed guidelines for the integration of migration into National Adaptation Plans (NAP): "The UNFCCC's national adaptation plan (NAP) could prove to be a key channel for ensuring mobility is addressed in national plans and strategies. Like its predecessor, the NAPA, the NAP focuses on the least developed countries, but the UNFCCC envisages the NAP as a relevant framework for all affected developing countries". (IOM 2014: 67).

\subsection{De-environmentalizing climate migration}

The mainstreaming of climate migration has gone hand in hand with its 'deenvironmentalization': the (mis)understanding of migration that informed the previous discourses has been gradually replaced by more accurate understandings of human mobility and of the ways in which ecological conditions influence it - thanks to the growing engagement of migration scholars ${ }^{7}$.

Reducing the maximalist model to the bone, it brings migration into the picture as a reactive survival strategy to which an individual/household/community is forced when confronting a dose of environmental stress in excess of its coping capacity. Migration signifies a failure to adapt: had an individual/household/community been able to withstand environmental stressors successfully, there would be no need to move (i.e. successful adaptation).

In contemporary debates, climate and environmental changes are understood as factors adding to and/or impacting on 'conventional' drivers of migration (e.g. see the model in

\footnotetext{
6 http://www.iom.int/cms/envmig

7 The case of Prof Richard Black is exemplary: once a fierce critic of the "myth" of environmental refugees (Black 2001), he has been a vocal proposer of the new, sounder approaches to the climatemigration nexus (e.g. Black et al. 2011; Black et al. 2013).
} 
Foresight 2011, Black et al 2013). The impacts of climate change on mobility are therefore discussed in the context of already existing migratory processes and the inter-related outcomes of mobility patterns, ranging from displacement to proactive labour migration (Foresight 2011; see ch. 12 IPCC 2014). Different forms of mobility form part of an adaptation continuum (Warner 2009; Beardsley and Hugo 2010), i.e. are among the multiple strategies through which communities and households react to crises but also adapt to changes. Crucially, the discourse is thus one of migration in the context of climate change, no longer limited to forced movements, but with mobility conceived as an array of (often interwoven) reactive and a proactive strategies and behaviours.

In a decisive turn, the failure to adapt is linked to immobility rather than to mobility; not only those displaced, but also the so-called "trapped population" (those who are unable to move due to lack of human, social, and financial capital)-are now identified as an adaptation failure (Black et al 2012).

On these grounds, a new wave of interventions have promoted (governed) migration as a potentially 'positive' form of adaptation and as a strategy for managing risks associated with changing environmental conditions (e.g. Barnett and Webber 2009; Foresight 2011, ADB 2012, Geddes and Jordan 2012; Banerjee et al 2013; Warner and Afifi 2014, Black, Bennett, Thomas, \& Beddington, 2011; ADB 2011; Warner et al 2013; 2014).

The forms of migration imagined and configured by this understanding are very different than those conveyed by the concept of 'climate refugees'. Climate migration in this framing entails voluntary movements, or at least migration (and possibly relocation) that is the result of a decision. These movements are understood as 'normal' (not pathological) and do not necessarily represent a threat. Climate migration is not anymore identified with floods of refugees, but rather understood as the set of impacts that climate change will exercise on existing, already functioning migration processes, for the most intraregional, and for the most configured as labour migration.

\subsection{Agents of Development / Agents of Adaptation}

In spite of the novelty it comes coated in, the re-conceptualization of migration amidst climatic and environmental change in effect entails primarily a repositioning rather than the creation of new approaches. The emerging discourses on climate change, migration and development owe a lot to the debates on the migration-development nexus discussed in Section 2. The discourses on migration as adaptation clearly echo the recent wave of (neoliberal) optimism that sees migration has an engine for development. As we will see in the following, the risk is that the discourses on climate migration gather a rather 
simplistic heuristic version of such models, inheriting from them also a number of shortcomings.

The rhetoric on the positive feedback loops ignited by migration and remittances echoes mainstream narratives on virtuous circles set in motion by migration that inform the discourse of international policy actors, such as IOM, the World Bank, the Asian Development Bank and UNDP. More specifically, the emerging discourses on 'migration as adaptation' are conceptually grounded in the merging of two theoretical approaches: NELM (Stark and Bloom 1985) and Sustainable Livelihoods Approach (SLA)(Chambers and Conway 1992).

In a 2008 IOM study, Kniveton at al. claim that "[t]aken together, the SLA and NELM approaches provide a way of understanding how households respond to climate shocks, and the extent to which migration is part of their response" (Kniveton et al 2008: 39). The potential descending from the merging these two approaches did not go unnoticed also among 'migration and development' scholars. De Haas in 2010 tried to elaborate a conceptual framework to overcome the structure/agency dichotomy by integrating and amending insights from NELM, livelihood perspectives in development studies and transnational perspectives in migration studies "which share several though as yet unobserved conceptual parallels" (De Haas 2010).

NELM is based on the idea that the decision to migrate for labour should not be considered as the attempt of a rational actor to maximize individual income, but rather as a household strategy to diversify the income streams (Stark \& Levhari 1982; Taylor 1999; Massey and Parrado 1998. Households, rather than individual, become the unit of decision making, as "migration decisions are often made jointly by the migrant and by some group of nonmigrants" (Stark and Bloom, 1985: 175). The implicit contract among these actors is that migrants are bound to remit. Spatial diversification of labour and resource-pooling help the household to mitigate risks (Arango, 2000), such as crop failure caused by changing weather patterns or environmental shocks. Migration as a risk minimizing strategy acts as a form of insurance or social welfare, for those countries where private insurance mechanisms are unavailable, imperfect or inaccessible to poor families (Massey at al 1993; Yang and Choi, 2007). Thereby, remitted assets cushion risk and might have a transformative impact, especially in rural economies (Taylor and Martin 2001).

Concurrently, SLA emerged within development debates as a holistic theory to understand rural poverty and to contribute to its eradication (Bebbington 1999; Carney 1998; Ellis 2000). SLA pivots on the idea that households possess a variety of natural, physical, financial, human and social assets (the so-called 'asset pentagon') all 
contributing to the household's livelihood. If one of the assets suffers a loss (due to various kind of shocks, including environmental ones), it can be compensated for by falling back on the other available assets (DFID, 2000).

The influential Foresight Report (2011), issued by the UK's Government Office for Science, is theoretically grounded on the integration of a specific understanding of migration (NELM), into the most prominent framework for understanding rural development (as exemplified in the asset pentagon, p. 33). Migration is hence re-conceptualized as a positive form of adaptation and research efforts are re-directed towards understanding "the role of migration in managing risks associated with changing environmental conditions" (Warner et al 2014: 1 see also Black, et al, 2011; Hugo 2008; Piguet 2010). The discourse on 'migration as adaptation' is in fact profoundly indebted to that conceptual framework. For instance, the United Nations University project "Where the rain falls" is conceptually grounded on NELM. Embracing the shift form the earlier 'climate change and migration' paradigm, the summary of the project frames migration as a risk management option vis-à-vis climatic stressors" (Warner et al 2014: 1) - and the 1982 paper by Stark \& Levhari is explicitly quoted as theoretical reference allowing to move the question from the identification of environmental drivers as the sole causal factors of mobility, to the role of migration as a risk mitigation strategy. The defining pillars of the mainstream and NELM-inspired articulation of the migration-development nexus are also replicated in the new problematization of climate migration.

Two things are worth noting here: Firstly, there has clearly been scant cross-fertilization among scholarships. Despite the fact that, since 2008, the SLA and NELM-based research design has provided the theoretical base for the new generation of studies within the migration and climate change research area, development scholars seem to have overlooked this contribution and refrained from contributing to the debate.

Secondly, critique of NELM and SLA previously articulated in 'migration and development' and critical geography studies are not taken into full consideration and only mentioned en passant by 'migration and climate change' scholars, who seldom benefit from the lesson learnt and hold to a rather simplified and heuristic version of the two approaches. A conspicuous body of work have cautioned against the wave of enthusiasm driven by surging remittances and all-to-easy linkages between remitted assets and poverty reduction, or development. Kapur (2005) has investigated the ideological dimension of the 'remittaces mantra', pointing at its proximity to a neoliberal agenda, interested in promoting "self-help" development, so that "immigrants, rather than governments, $[\ldots]$ become the biggest provider of "foreign aid" (Kapur, 2005:10). 
Crucial questions like: Who is going to benefit from remittances? What are their impacts on existing (gendered) power relations? have been overlooked. Both NELM and SLA "rarely include analysis of unequal power relations in the migration process, and within the conflicting networks of migrant and other non migrant people involved, such as those between or within communities and household, men and women, or different age groups" (Thieme 2011: 332).

The attention to the household as decision making unit and remittances recipient has been criticized for neglecting power inequalities at both the community and the intrahousehold level and for its limited versatility, as it focuses on male-dominated and predominately temporary, circular labour migration (Aragno, 2000; Lindley, 2009 de Haas, 2010; Kunz 2012).

All of these critiques could be easily replicated for the literature arguing for the 'migration as adaptation' thesis. Root causes of poverty and inequality remain still undertheorised and hidden behind a naturalization of the drivers of mobility as well as an atomization of their impact. While praising remittances for adaptation, important (gendered) dimensions of migration and their embeddedness in the material conditions of labour and remittance economies remains still uncharted territory:

\section{The dark side of development?}

It is too early to evaluate the fate, impacts and 'success' of these emerging discourses, which are still pretty much object of political negotiation and yet to inform actual policies, and only a limited number of studies (Felli 2013; Bettini 2014; Methmann and Oels 2015) examine the contours and implications of the shift to more optimistic discourses on the nexus migration-adaptation. The conclusions of such studies, together with the insights offered by our analysis here, seem to question both the novelty and the prospect for the emerging discourses on 'migration as adaptation' to represent a democratization of the debate and an emancipatory turn. The 'reasons for concern' can be summarized in four key points. To begin with, the emergence of the new model and the narratives on 'migration as adaptation' has brought a breath of fresh air into a debate previously soaked in environmental determinism and immobilized by the opposition between the alarmism of some and reluctance of others to deal with the phenomenon. It has also been instrumental to involving actors in the mainstream fora of international development and migration governance like ADB, IOM and the World Bank, for which the 'environmental crisis' narrative of the past was probably unpalatable.

Second, the new discourses bring different subjectivities and characters to the center stage: the figure of climate refugee (destitute victim, the potential sources of insecurity) 
is increasingly supplanted by the climate migrant, a (pro)active 'agent of adaptation' and eventually, a 'resilient subject' (Felli 2013; Bettini 2014). With a transition, as captured by Methmann and Oels' trenchant critique of such emphatic narratives, from climate refugees to be protected to migrants as 'warriors of resilience' eager to be empowered (Methmann and Oels 2015). In this, the emerging discourses clearly follow the steps of the optimistic turns in the 'migration and development' debate (inheriting also their weak points, see the previous sections).

Third, the 'positive' narratives on climate migrants as adaptive agents should not be mistaken for a plea for free migration. In fact, they envision very disciplined and specific forms of mobility: the aim is to facilitate 'virtuous' labour migration, in particular temporary or circular South-South workforce movements (cfr. Bettini 2014: 185ff).

Fourth, labour migration is acknowledged a potential benefit for adaptation and resilience thanks to its capacity to generate individual - and at times collective (Scheffran et al 2012) - financial and social remittances. Remittances are preached for representing a quick and targeted form of self-insurance, complementing, when not substituting weak or inexistent formal insurance mechanisms and social security: the quickly flow in in case of shocks (such as 'natural' disasters), contribute to recovery and thereby also avoid displacement (e.g. Foresight 2011: 21, 144; ADB 2012: 42). Relatedly, remittances can also facilitate long-term strategies of risk minimization, not least by financing the underwriting of insurances (Foresight 2011: 53). Even more importantly in the context of this paper, remittances are seen as the trigger igniting positive feedback loops that, through a series of beneficial impacts of migration, increase the social and human capital held by households and thereby make them resilient. This is the process labelled by some 'content migration' (Warner and Afifi 2013), envisioned as part of a process of potential transformative adaptation bringing populations out of vulnerability while lifting them out of poverty and skewed power relations.

The last two points highlight the extent to which the emerging discourses articulate 'development' and its connections to mobility and climate change in a very peculiar way. The growing centrality of development and the fact that climate migration has become a salient topic beyond environmental circles should be not taken solely as a sign of a long due 'de-environmentalization' of the debate. As we have seen, the increasing involvement of migration and development scholars and practitioners has contributed to overcoming the environmental determinism that permeated the 'old' narratives on climate refugees. But this has not entailed a recognition of the political (instead of environmental) character of the nexus between climate change and mobility. Bringing 'development' on the table has not rhymed with focusing on the political, ecological, and economic 
processes that determine whether (im)mobility is a self-reinforcing symptom of marginalization or an occasion for emancipation and reduction of vulnerability. Rather, the emerging discourses reproduce (quite uncritically) the optimistic sides of the migration and development debate, articulated along the lines and strategies of contemporary neoliberal management of labour. Significantly, when mobilized to cope with the impacts of climate change, labour migration becomes a means to govern risk via the disciplining of the behaviour of ecologically and economically vulnerable populations. Basically, it is through labour markets that the vulnerable are transformed into adapted, resilience subjects, and it is primarily though remittances that such a transformations is envisioned to take place. Such an articulation is far from unproblematic, not least as, at the end of the day, it shifts the responsibility (for successful adaptation, for survival) onto the vulnerable. It represent an attempt to individualize climate adaptation in ways that extend a series of neoliberal economic relations that reproduce the conditions out of which vulnerabilities emerge (Felli 2013). Moreover, this 'transformative' vision is not without losers - the gates of migration are open to those docile subjects able and allowed to follow the signals of labour market. The ways in which the virtuous circles and adaptive potentials of mobility can be extended to those who for some reasons result unfit to this logic (or are left outside labour migration quotas) is unclear - as unclear is their fate (on the problem of the 'unfit', see Bettini 2014).

\section{Conclusions}

This article has highlighted that climate change, migration and development are increasingly being addressed together; in particular, the question of how climate change will influence migration has been 'de-environmentalized' and important actors concerned with development and migration are 'colonizing' an issue once belonging to climate and environmental arenas - which is not per se a negative evolution.

It is worth stressing that the goal of this opening intervention is not to sponsor any apologetic narrative that joins climate adaptation, migration and development - the point we are making is not normative, and we are not implying that associating climate change, migration and development is per se positive or undesirable. The previous sections have showed that while the models that inform these interactions are hardly new and empirically controversial (as the literature on 'migration and development' testifies), they are even more contested from a political and normative angles. Significantly, the association migration-climate-development is structured along a markedly neoliberal line. 
To be clear, we have no nostalgia for the Malthusian discourses on mounting waves of climate refugees that misunderstood and pathologized migration. But it is worth signalling that the emergent discourses are not bringing together climate change, migration and development to 'politicize' climate vulnerability and adaptation. They are not primarily 'denouncing' the series of structural inequalities that shape vulnerabilities and impede to many the exercise of mobility as a moment of empowerment, as a move in search of a life freer from the adverse impacts of climate change as much as from political oppression and economic exploitation and deprivation. The idea of 'migration as adaptation' has so far primarily reproduced the neoliberal version of the classical optimist take on the migration-development nexus, through which mainstream international actors have tried to foster development and to discipline mobility in the last couple of decades. The extent to which this can prove a 'positive' evolution of the debate on climate and migration is up to debate.

\section{References}

Agrawal, A. \& Lemos, M. C. 2015. Adaptive development. Nature Climate Change, 5, 185187.

Agunias, D. R. and Newland, K. (2007). Circular migration and development: Trends, policy routes and ways forward. MPI policy brief. Washington, DC: Migration Policy Institute.

Almeida, C. C. 1973 "Emigration, Espace et Sous-Developpement." International Migration XI(3):112- 117.

Asian Development Bank [ADB] 2012. Climate Change and Migration in Asia and the Pacific, Manila: ADB. Available at: http://www.adb.org/publications/addressingclimate-change-and-migration-asia-and-pacific

Banerjee, S., Gerlitz, Y.S. and Hoermann, B. (2011): 'Labour Migration as a response to water hazards in the Hindu-Kush-Himalayas', Kathmandu: International Center for Integrated Mountain Development ICIMOD.

Baldwin, A. (2012) Orientalising environmental citizenship: Climate change, migration and the potentiality of race. Citizenship Studies 5-6: 625-40.

Barnett J and Webber M (2009) Accommodating Migration to Promote Adaptation to Climate Change. World Bank Policy Research Working Paper, 5270, pp. 1-62.

Basher, R.: Global early warning systems for natural hazards: Systematic and people-centred, Philos. Trans. Roy. Soc. A, 364, 2167-2182, 2006.

Beardsley DK, Hugo GJ. 2010. Migration and climate change: examining thresholds of change to guide effective adaptation decision-making. Population and Environment 32 (2-3): 238-262.

Bebbington, A. 1999. Capitals and Capabilities: A Framework for Analyzing Peasant Viability, Rural Livelihoods and Poverty, World Development, 27 (12), 2021-2044. 
Bettini, G. 2013. Climates barbarians at the gate? A critique of apocalyptic narratives on climate refugees Geoforum, 45, 63-72.

Bettini, G. 2014. Climate migration as an adaption strategy: de-securitizing climateinducedmigration or making the unruly governable? Critical Studies on Security, 2, 180-195.

Bettini, G., \& Andersson, E. 2014. Sand Waves and Human Tides: Exploring Environmental Myths on Desertification and Climate-Induced Migration. The Journal of Environment \& Development, 23(1), 160-185.

Biermann, F. \& Boas, I. 2008. Protecting Climate Refugees the Case for a Global Protocol. Environment, 50, 8-16.

Biermann, F. \& Boas, I. 2010. Preparing for a Warmer World: Towards a Global Governance System to Protect Climate Refugees. Global Environmental Politics, 10, 60-88.

Black R. 2001. Environmental refugees: Myth or reality? New issues in refugee research. Geneva: United Nations High Commissioner for Refugees (UNHCR).

Black R, Kniveton D, Skeldon R, Coppard, D. Murata A, Schmidt-Verkerk K. 2008. Demographics and climate change: Future trends and their policy implications for migration, DFID working paper No. 33. Brighton: Development Research Centre on Migration, Globalisation and Poverty.

Black, R., S. R. G. Bennett, S. M. Thomas, and J. R. Beddington. 2011. Climate Change: Migration as Adaptation. Nature, 478 (7370), 447-449

Black R, Adger WN. Arnell NW. et al. 2012. Migration, immobility and displacement outcomes following extreme events. Environmental Science and Policy 27(1): 532-43.

Black, R., N. W. Arnell, W. N. Adger, D. Thomas, and A. Geddes. 2013. Migration, Immobility and Displacement Outcomes Following Extreme Events. Environmental Science \& Policy, 27 (S 1):S32-S43

Boano C, Zetter R, Morris T. 2007. Environmentally displaced people: Understanding the linkages between environmental change, livelihood and forced migration. Oxford: Refugee Studies Centre.

Brown, O. 2008. Migration and Climate Change. Geneva: IOM.

Carney, D. 1998. Sustainable Livelihoods: What contribution can we make? London: Department for International Development (DFID).

Castles, S. 2002. Environmental change and forced migration: making sense of the debate. New issues in Refugee Research - UNHCR working paper 70.

Castles, S. 2011. Concluding remarks on the climate change-migration nexus. In: Piguet, E., Pecoud, A. \& De Guchteneire, P. (eds.) Migration and Climate Change. Cambridge: Cambridge University Press.

Chambers, R. and G.R. Conway 1992. Sustainable rural livelihoods: Practical concepts for the 21st century, IDS Discussion Paper 296, Institute of Development Studies, University of Sussex, Brighton.

Christian Aid. 2007. Human Tide. The Real Migration Crisis. London: Christian Aid.

Council of the European Union. 2008. Climate Change and International Security - Report from the Commission and the Secretary-General/High Representative. Brussels, 7249/08, Available from http://goo.gl/djwYzt.

de Haas, H. 2010. Migration and development: a theoretical perspective. International Migration Review, 44, 227- 264.

de Haas, H. 2012. The Migration and Development Pendulum: A Critical View on Research 
and Policy. International Migration, 50(3), 8-25.

Dorantes, C. and Pozo, S. 2006. 'Remittances as Insurance: Evidence from Mexican Immigrants', Journal of Population Economics, 19(2), 227-254. Durand, J., Kandell, W., Parrado, E., \& Massey, D. S. 1996. International migration and development in Mexican communities. Demography, 33(2), 249-64.

Deshingkar, P. 2012. Environmental risk, resilience and migration: Implications for natural resource management and agriculture. Environmental Research Letters 7: 015603.

El-Hinnawi, E. 1985. Environmental Refugees. Nairobi: UNEP.

Evans, B. and Reid, J. 2013. Dangerously exposed: The life and death of the resilient subject. Resilience 1(1): 1-16.

Ellis, F. 2000. Rural livelihoods and diversity in developing countries. Oxford, UK: Oxford University Press.

Fagen, P. and Bump, M. 2006. Remittances in Conflict and Crises: How remittances sustain livelihoods in war, crises and transition to peace, International Peace Academy. Available

at: www.ipacademy.org/Programs/Research/ProgReseSecDev_Pub.htm

Faist, T. 2008. Migrants as transnational development agents: An inquiry into the newest round of the migration- development nexus. Population, Space and Place 14(1): 2142.

Faist, T. 2009. Transnationalization and development: Toward an alternative agenda. Social Analysis 53(3): 38-59.

Faist, T. Schade J (eds.). 2013. Disentangling Migration and Climate Change. Dordrecht: Springer.

Felli, R. 2013. Managing Climate Insecurity by Ensuring Continuous Capital Accumulation: 'Climate Refugees' and 'Climate Migrants'. New Political Economy, 18, 337-363.

Foresight. 2011. Final Project Report - Foresight: Migration and Global Environmental Change. London: Government Office for Science.

Geddes, A., and A. Jordan. 2012. Migration as Adaptation? Exploring the Scope for Coordinating Environmental and Migration Policies in the European Union. Environment and Planning C, 30 (6): 1029-1044.

Gemenne, F. 2011a. Why the numbers don't add up: A review of estimates and predictions of people displaced by environmental changes. Global Environmental Change 21 (1): 41-9.

Gemenne, F. 2011b. How they became the human face of climate change. Research and policy interactions in the birth of the 'environmental migration' concept. In: Piguet, E., Pecoud, A. \& De Guchteneire, P. (eds.) Migration and Climate Change. Cambridge: Cambridge University Press.

Gemenne, F. \& Bruecker, P. 2015. From the Guiding Principles on Internal Displacement to the Nansen Initiative: What the Governance of Environmental Migration Can Learn from the Governance of Internal Displacement. International Journal of Refugee Law, 27(2): 245-263. doi:10.1093/ijrl/eev021

Gill, N. 2010. "Environmental Refugees": Key Debates and the Contribution of Geographers, Geography Compass, 4/7, pp. 861-71.

Hartmann, B. 2010. Rethinking Climate Refugees and Climate Conflict: Rhetoric, Reality and the Politics of Policy Discourse. Journal of International Development, 22 (2): 233-246.

Homer-Dixon, T.F. 1999. Environment, Scarcity and Violence. Princeton, NJ: Princeton 
University Press.

Hugo, G. 2008. Migration, Development and Environment, IOM Migration Research Series, Paper n. 35, Geneva: IOM.

Hugo, G. 2011. Future demographic change and its interactions with migration and climate change, Global Environmental Change 21S (2011) S21-S33

IPCC 2014. Summary for Policy Makers. In: Climate Change 2014: Impacts, Adaptation, and Vulnerability. Contribution of Working Group II to the Fifth Assessment Report of the Intergovernmental Panel on Climate Change.. Cambridge, United Kingdom and New York, NY, USA: Cambridge University Press.

IOM. 2005. The Millennium Development Goals and Migration, available at www.iom.int/jahia/webdav/site/myjahiasite/shared/.../mrs20.pdf

IOM 2014. Human mobility in the context of climate change. Geneva: IOM.

Jakobeit, C. \& Methmann, C. 2012. 'Climate Refugees' as dawning catastrophe? A critique of the dominant quest for numbers. In: SCHEFFRAN, J., BRZOSKA, M., BRAUCH, H. G., LINK, P. M. \& SCHILLING, J. (eds.) Climate change, human security and violent conflict: challenges for societal stability. New York: Springer.

Kapur, D. 2005. Remittances: The New Development Mantra? In Samuel Munzele Maimbo and Dilip Ratha (Eds.), Remittances: Development Impact and Future Prospects. The World Bank: Washington, D.C.

Kaelin, W. \& Schrepfer, N. 2012. Protecting People Crossing Borders in the Context of Climate Change: Normative Gaps and Possible Approaches. Legal and Protection Policy Research Series. UNHCR.

Kniveton D, Schmidt-Verkerk K, Smith C, Black R. 2008. Climate change and migration: Improving methodologies to estimate flows, in IOM Migration Research Series. Geneva: IOM.

Kniveton D., Smith C., and Wood, S. 2011. Agent-based model simulations of future changes in migration flows for Burkina Faso. Global Environmental Change 21: 534540.

Kunz, R. 2011. The Political Economy of Global Remittances: Gender, Governmentality and Neoliberalism. London: Routledge.

Laczko, F. and Collett, E. 2005. Assessing the Tsunami's Effects on Migration. Feature story on Migration Information Source, Migration Policy Institute,

http://www.migrationinformation.org/feature/display.cfm?ID=299

Laczko, F. 2008. Migration, Development and Environment: Introductory remarks. SSRC Migration \& Development Conference Paper No. 7, Available at: http://goo.gl/eM5HtP (last retrieved February 2014).

Laczko, F. and Aghazarm, C. 2009. Migration, Environment and Climate Change. Geneva: International Organization for Migration.

Le De, L., Gaillard, J., \& Friesen, W. 2013. Remittances and disaster: A review. International Journal of Disaster Risk Reduction, 4, 34-43.

Lindley, A. 2009. Remittances and Conflict: Some conceptual issues. Jahrbücher für National Ökonomie und Statistik 229(6) , 774-786.

Massey, D. S., J. Arango, G. Hugo, A. Kouaouci, P. Adela, and J. E. Taylor. 1998. Worlds in Motion: Understanding International Migration at the End of the Millennium, International Studies in Demography. Oxford: Clarendon Press.

Massey, D.S., J. Arango, G. Hugo, A. Kouaouci, A. Pellegrino, and J.E. Taylor 1998. Worlds in Motion, Understanding International Migration at the End of the Millenium, Clarendon 
Press, Oxford.

McLeman R. 2012. Developments in modelling of climate change-related migration. Climatic Change. 117 (3): 599-611.

McLeman, R. and Hunter, L. 2010. "Migration in the context of vulnerability and adaptation to climate change: insights from analogues", WIREs Climate Change, Volume 1, pp. 450-461.

McNamara, K. E. 2007. Conceptualizing discourses on environmental refugees at the United Nations. Population and Environment, 29, 12-24.

Methmann, C. \& Oels, A. 2015. From 'fearing' to 'empowering' climate refugees: Governing climate-induced migration in the name of resilience. Security Dialogue, 46, 51-68.

Morrissey, J. 2009. Environmental Change and Forced Migration: A State of the Art Review, Oxford, Refugee Studies Centre, Oxford Department of International Development, Queen Elizabeth House, University of Oxford.

Mayer, B. 2013. Constructing "Climate Migration" as a Global Governance Issue: Essential Flaws in the Contemporary Literature. McGill International Journal of Sustainable Development Law and Policy, 9.

Myers, N., and J. Kent. 1995. Environmental Exodus. An Emergent Crisis in the Global Arena. Washington, DC: Climate Institute.

Myers, N. 1997. Environmental Refugees. Population and Environment, 19 (2): 167-182.

Myers N. 2002. Environmental refugees: A growing phenomenon of the 21st century. Philosophical Transactions of the Royal Society 357: 609-13.

Myers, N. 2005. Environmental Refugees: An Emergent Security Issue. Prague: 13th Economic Forum, May 23-27.

Oels, A. (2008), Asylum Rights for Climate Refugee? From Agamben's Bare Life to the Autonomy ofMigration', Annual Convention of the International Studies Association, San Francisco, 26-29 March 2008.

Oels, A. 2013. Rendering Climate Change Governable by Risk: From Probability to Contingency. Geoforum 45: 17-29.

Paulson, D.D. 1993. Hurricane hazard in western Samoa. Geographical Review 83: 43-53.

Pearce, F. 2011. Searching for the Climate Refugees, New Scientist, 210 (2810), p. 6.

Piguet, E. 2008. Climate Change and Forced Migration, New Issues in Refugee Research, 153, pp. 1-9.

Piguet, A. 2010. 'Linking climate change, environmental degradation, and migration: a methodological overview', WIREs Climate Change 1:4, pp. 517-524.

Piper, N. 2009.Guest editorial - The complex interconnections of the migrationdevelopment nexus: A social perspective. Population, Space and Place, 15: 93-101.

Raghuram, P. (2009). Which Migration, What Development? Unsettling the Edifice of Migration and Development, Population, Space and Place, 15, 103-17.

Reuveny, R. 2007. Climate Change-Induced Migration and Violent Conflict. Political Geography 26 (6): 656-673.

Ratha, D. 2003. Workers" Remittances: An Important and Stable Source of Development Finance. In T. W. Bank, ed. Global Development Finance. Washington, DC: The World Bank, pp. 157-175.

Ratha, D. 2005. Remittances: An Important and Stable Source of External Development Finance." Samuel Munzele Maimbo and Dilip Ratha (eds.), Remittances: Development Impact and Future Prospects. The World Bank: Washington, D.C.

Scheffran, J., Marmer and Sow. 2012. Migration as a contribution to resilience and 
innovation in climate adaptation: Social networks and co-development in Northwest Africa. Applied Geography, 22, 119-127.

Smith, P. J. 2007. Climate Change, Mass Migration and the Military Response. Orbis, 51, 617-633.

Spaan E, van Naerssen T and Hillmann F. . 2005. Shifts in the European discourses on migration and development. Asian and Pacific Migration Journal 14(1-2): 35-70.

Stark O, and D.E. Bloom. 1985. The New Economics of Labor Migration. American Economic Review 75, 173-8

Sriskandarajah, D. 2002. The Migration-Development Nexus: Sri Lanka Case Study. International Migration , 40(5), 283-307Stark 0, Levhari D. 1982. On Migration and Risk in LDCs. Economic Development and Cultural Change, 191-6.

Stern, N. 2007. The economics of climate change. The Stern review. Cambridge:

Cambridge University Press.

Suhrke, A. 1994. Environmental degradation and population flows. Journal of International Affairs 47(2):473-96.

Tacoli, C. 2009. Crisis or adaptation? Migration and climate change in a context of high mobility. Environment and urbanization., 21, 513-525.

Tacoli, C. and Mabala, R. 2010. Exploring mobility and migration in the context of ruralurban linkages: why gender and generation matter, Environment and Urbanization 22: pp. 389-396.

Taylor, M. 2009, 'Displacing Insecurity in a Divided World: Global Security, International Development and the Endless Accumulation of Capital', Third World Quarterly, 30 (1), 147-62.

Warner, K. 2009. Global environmental change and migration : Governance challenges. Global Environmental Change 20, 402-413.

Warner, K., Afifi, T., Henry, K., Rawe, T., Smith, C. \& De Sherbinin, A. 2012. Where the rain falls: climate change, food and livelihood security, and migration - Global Policy Report, Bonn, UNU-EHS (United Nations University Institute for Environment and Human Security.

Warner, K. \& Afifi, T. 2014. Where the rain falls: Evidence from 8 countries on how vulnerable households use migration to manage the risk of rainfall variability and food insecurity. Climate and Development, 6, 1-17.

White, G. 2011. Climate Change and Migration: Security and Borders in a Warming World. Oxford: Oxford University Press.

Yang, D., \& Choi, H. J. 2007. Are remittances insurance? Evidence from rainfall shocks in the Philippines. The World Bank Economic Review, 21, 219-248. 